\title{
Detection of Antibodies to Influenza Virus M Protein by an Enzyme-Linked Immunosorbent Assay
}

\author{
M. W. KHAN, ${ }^{1}$ D. J. BUCHER, ${ }^{1 *}$ A. K. KOUL,${ }^{1}$ G. KALISH,${ }^{2}$ H. SMITH, ${ }^{3}$ AND E. D. KILBOURNE ${ }^{1}$ \\ Departments of Microbiology ${ }^{1}$ and Biomathematical Sciences, ${ }^{3}$ Mount Sinai School of Medicine of the City \\ University of New York, New York, New York 10029, and American Cyanamid Company, ${ }^{2}$ Medical Research \\ Division, Lederle Laboratories, Pearl River, New York $10965^{2}$
}

Received 5 April 1982/Accepted 29 July 1982

\begin{abstract}
An enzyme-linked immunosorbent assay test system was developed in which purified influenza virus $\mathbf{M}$ protein was used for the detection of $\mathbf{M}$ antibody in human sera. Antibody levels to influenza $A$ virus $M$ protein were monitored in sera from a vaccine study population by using an enzyme-linked immunosorbent assay technique with purified $M$ protein as the adsorbent antigen. A 10-fold variation in titers of preexisting $\mathbf{M}$ antibody was observed in this population of young adults. Increases of anti-M titer of 7- to 24-fold were observed upon immunization with Formalin-inactivated vaccine or after natural infection. The antibody response to $M$ protein was dissociated from the response to the hemagglutinin or neuraminidase antigens. The $M$ antibody response preceded or was coincident with the antibody response to $\mathrm{H} 1$ hemagglutinin upon natural exposure to circulating virus.
\end{abstract}

M (matrix) protein is a major type-specific antigen of influenza viruses (14). The significance of antibodies to $M$ protein as related to disease in influenza virus infection is unknown. Antibodies to $M$ protein have been found by single radial diffusion assays $(5,11)$ in persons with severe illness due to influenza virus infection. The advent of more sensitive techniques, such as the enzyme-linked immunosorbent assay (ELISA), permits further evaluation of $M$ antibody concentrations in serum after exposure to influenza viral antigens.

The use of purified antigens in the ELISA test system permits a molecular dissection of the host antibody response to artificial immunization or infection with influenza virus. Masihi and Lange (10) used an ELISA system for detection of antibodies to nucleoprotein. Purified influenza viral hemagglutinin (HA) (12) and neuraminidase (NA) (7) have been used as adsorbents on microtiter plates to quantitate antibody responses to these viral components. The availability of purified $\mathbf{M}$ protein isolated by sodium dodecyl sulfate (SDS) gel chromatography $(2,3)$ permitted the development of an ELISA system for detection of antibodies to this viral antigen.

\section{MATERIALS AND METHODS}

Preparation of $\mathbf{M}$ protein. $\mathbf{M}$ protein was isolated from an unused batch of swine influenza vaccine donated by the Drug Directorate, Health Protection Branch, Bureau of Biologics, Ottawa, Ontario, Canada. The vaccine was prepared with the high-yielding recombinant strain X-53a, which derives its HA and
NA from the parent strain $\mathrm{A} / \mathrm{NJ} / 11 / 76$ (H1N1) and its internal proteins, including $M$ protein, from the parent strain A/PR/8/34 (H1N1) $(8,15)$. The virus was inactivated with $\beta$-propiolactone in the course of vaccine production.

Pelleted vaccine virus was treated as previously described, and $M$ protein was isolated by SDS gel chromatography without prior reduction $(2,3)$. Chromatography on Sepharose CL-6B (Pharmacia Fine Chemicals, Inc., Piscataway, N.J.) was used for initial separation of the major viral components; additional purification of $\mathbf{M}$ protein was achieved by recycling the $M$ protein solutions on Bio-Gel A-5m (Bio-Rad Laboratories, Richmond, Calif.) columns. Purity of $\mathbf{M}$ protein was monitored by SDS-polyacrylamide gel electrophoresis by the method of O'Farrell (13). M protein-containing fractions were concentrated by ultrafiltration to 1.0 to $2.0 \mathrm{mg} / \mathrm{ml}$ (9) as described previously $(3,4)$. SDS was not removed from $M$ protein solutions.

ELISA. The procedure for ELISA used was a modification of that used by Voller and co-workers (17). Immulon plates, flat-bottomed microtiter plates (Dynatech Laboratories, Alexandria, Va.), were sensitized with $100 \mu$ l of $M$ protein antigen $(400 \mathrm{ng} / \mathrm{ml})$ in $0.15 \mathrm{M} \mathrm{Na}_{2} \mathrm{CO}_{3}-0.035 \mathrm{M} \mathrm{NaHCO}_{3}$ buffer (pH 9.6) and incubated overnight in a moist chamber at $4^{\circ} \mathrm{C}$. The optimal concentration of $\mathbf{M}$ protein was previously ascertained by checkerboard titration of the antigen with hyperimmune antiserum (rabbit) to $M$ protein. Wells were washed three times in a solution of $0.15 \mathrm{M}$

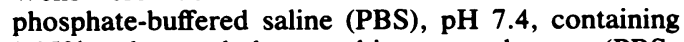
$0.05 \%$ polyoxyethylene sorbitan monolaurate (PBSTween 30), and $100 \mu \mathrm{l}$ of a solution of PBS-Tween containing $0.5 \%$ bovine serum albumin was added to each well. Plates were then placed in a refrigerator for $1 \mathrm{~h}$ before $100 \mu \mathrm{l}$ of a 1:50 serum dilution (in PBS- 
Tween containing $2 \%$ allantoic fluid) was added to the plate and twofold dilutions were made directly in the wells. Control wells in which there was no antigen or no antiserum and others in which normal allantoic fluid was used as antigen at a protein concentration equivalent to that of the viral antigen were also included in each test. Plates were again incubated overnight (a procedure which we found enhanced the sensitivity of the test [7]) and washed three times with PBS-Tween, and $100 \mu$ of an optimal dilution (in PBSTween- $0.5 \%$ bovine serum albumin) of goat antihuman immunoglobulin $\mathrm{G}$ Fab serum conjugated with alkaline phosphatase (Dynatech Diagnostics, Inc., South Windham, Maine) was added to each well. Plates were incubated overnight and washed as before and $100 \mu \mathrm{l}$ of a solution of $p$-nitrophenylphosphate substrate $(1 \mathrm{mg} / \mathrm{ml}$; Sigma Chemical Co., St. Louis, Mo.) dissolved in $10 \%$ diethanolamine buffer was added to each well. After a 45-min incubation at room temperature or as positive control sera reached a predetermined standard titer for each serum, the reaction was immediately stopped with $25 \mu$ l of $3 \mathrm{M} \mathrm{NaOH}$ per well. The color reaction was read directly, using a Microelisa 590 colorimeter equipped with a $405-\mathrm{nm}$ filter. No significant intraplate or interplate variation was observed, nor was any significant day-to-day variation noted. All sera (five bleedings of each subject) were assayed in parallel over the same time period.

Serum samples. Human sera were obtained from a vaccine study performed in collaboration with Lederle Laboratories, Pearl River, N.Y. (see reference 7). Volunteers were bled before immunization (serum sample 1) with an NA-specific, Formalin-inactivated influenza virus vaccine (H7N1), a recombinant containing the HA from A/Equine/Prague/1/56 and the NA from A/USSR/92/77; a conventional Formalin-inactivated influenza virus vaccine (A/USSR/92/77); or a placebo (vaccine diluent only). A timetable for the vaccine study is shown in Table 1 . Serum sample 2 was taken 1 month after the first dose of vaccine, and at this time a second vaccine dose was administered. A third serum sample was taken 2 weeks after this second vaccine dose. Approximately 6 months after initiation of the vaccine program or 4.5 months after collection of sample 3, an $\mathrm{H} 1 \mathrm{~N} 1$ virus (similar to $\mathrm{A} /$ Brazil/11/78) was circulating in this vaccine population. Clinical symptoms of influenza developed in some subjects (ill) between periods 3 and 5 ; other subjects were later shown to have been infected by serological evidence but did not become ill (non-ill). Antibody response to infection is defined by serum samples 4 and 5.
Vaccine immunogens. Vaccinated subjects were injected with one of two experimental Formalin-inactivated vaccines prepared by Lederle Laboratories. The conventional vaccine (H1N1; see Table 2$)$ contained A/USSR/90/77 (H1N1) virus containing 338 chicken cell-agglutinating units per $0.5-\mathrm{ml}$ dose. The NA-specific vaccine contained the $\mathrm{X}-68$ recombinant virus (H7N1) (7) with 250 chicken cell-agglutinating units per dose.

HI and NA inhibition assays. Conventional techniques were used in measuring $\mathrm{HA}$ and NA antibodies $(1,6,16)$. The recombinant viruses used for measuring hemagglutination inhibition (HI) antibodies contained an irrelevant NA (N7) and were disrupted with ether [A/Brazil/11/78-Equine/Prague/1/56 (H1N7) or A/ USSR/92/77-Equine/Prague/1/56 (H1N7)]. For measurement of $\mathrm{HI}$ responses in subjects given $\mathrm{H} 7 \mathrm{~N} 1$ (NA-specific) vaccine, wild-type strain A/Equine/ Prague/1/56 (H7N7) virus was used. NA antibodies were measured by the NA inhibition assay or by an ELISA technique in which an $\mathrm{H} 6 \mathrm{~N} 1$ recombinant was used as described by Khan et al. (7). All sera (five samples from each subject) were assayed on the same day.

Calculation of titers. The $\mathrm{HI}$ titer was recorded as the reciprocal of the dilution in a twofold dilution series (beginning with a 1:10 dilution of a receptordestroying, enzyme-treated serum sample) that gave complete inhibition of hemagglutination of $0.5 \%$ chicken erythrocytes. The NA inhibition titer was recorded as the reciprocal of the dilution of antiserum in a 3.2fold dilution series that inhibited $50 \%$ of the enzyme activity. Endpoint titers were obtained by interpolation between the appropriate dilutions to obtain the value for $50 \%$ inhibition of enzyme activity (16). ELISA titers were obtained similarly by interpolation, except instead of a $50 \%$ inhibition of enzyme activity, the endpoint titer was calculated at an absorbance reading of 0.3 optical density units (7). This value was chosen because it was within the linear range on a graph of optical density versus serum dilution (7).

\section{RESULTS}

Definition of $M$ protein preparation. The $M$ protein preparation employed as adsorbent was analyzed by SDS-polyacrylamide gel electrophoresis (Fig. 1). The preparation was homogeneous, with a single species migrating with the molecular weight $(25,000)$ characteristic of $\mathbf{M}$ protein (3). Immunodiffusion of this preparation versus serum from a subject who showed sero-

TABLE 1. Chronology of vaccine study

\begin{tabular}{|c|c|c|}
\hline $\begin{array}{l}\text { Serum } \\
\text { sample }\end{array}$ & $\begin{array}{l}\text { Time from } \\
\text { first vaccine } \\
\text { dose }\end{array}$ & Event \\
\hline $\begin{array}{l}1 \\
2 \\
3\end{array}$ & $\begin{array}{l}1 \text { day } \\
4 \text { weeks } \\
6 \text { weeks }\end{array}$ & $\left.\begin{array}{l}\text { First vaccine dose } \\
\text { Second vaccine dose }\end{array}\right\}$ Vaccine response \\
\hline $\begin{array}{l}4 \\
5\end{array}$ & $\begin{array}{l}24 \text { weeks } \\
26 \text { weeks }\end{array}$ & Exposure to infection (H1N1 Brazil-like virus present in community) \\
\hline
\end{tabular}




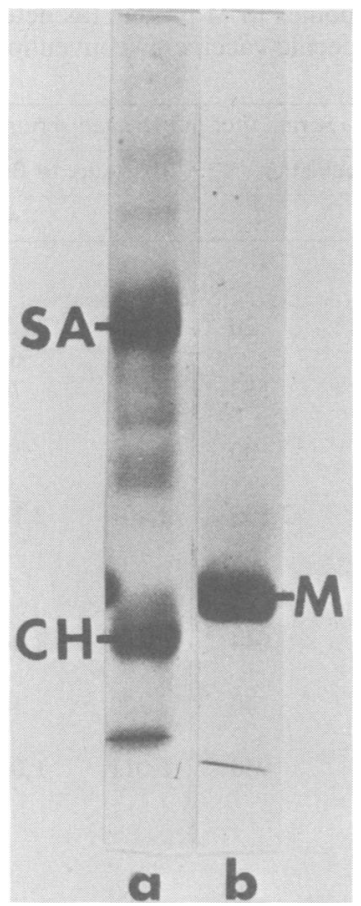

FIG. 1. (a) Standard proteins. (b) SDS-polyacrylamide gel electrophoresis of purified $\mathbf{M}$ protein preparation employed as adsorbent on microtiter plates for assay of $M$ protein antibodies. Electrophoresis was performed by the method of O'Farrell (13). SA, Serum albumin (molecular weight, 68,000); $\mathrm{CH}$, chymotrypsinogen (molecular weight, 25,700). Approximately 10 $\mu \mathrm{g}$ of $\mathbf{M}$ protein was loaded on the gel. Staining was performed with Coomassie blue.

logical evidence of infection with H1N1 (Brazil), as determined by $\mathrm{HI}$ tests, revealed the presence of a single antigen reactive with all viral subtypes tested (Fig. 2). These results provided further evidence of the purity of the $M$ protein preparation used in the ELISA system for detection of antibodies specific for $M$ protein.

Preexisting $M$ protein antibody titers. Preexisting anti-M titers among the 30 subjects ranged from 117 to 1,319 , with five subjects having titers in excess of 1,000 (Table 2). Geometric mean titers (GMTs) among the three groups ranged from 371 to 575 (Table 3). These differences were not statistically significant as evaluated by the $F$ test $(F[2,27]=0.94$ NS).

Antibody response to vaccination. All subjects (nine of nine) immunized with NA-specific vaccine displayed a rise in titer of $\mathbf{M}$ protein antibodies. This level of response was highly significant as evaluated by the $t$ test $(P<0.001)$. Two subjects immunized with NA-specific vaccine showed rises in titer above 2,500; subject 120 had a sevenfold rise in titer $(400$ to 2,883$)$, and subject 206 had a fourfold rise $(670$ to 2,692$)$. No significant changes in $\mathbf{M}$ antibody titer were observed among subjects who received conventional vaccine or placebo injections.

Response to the HA antigen was also significantly greater for the NA vaccine group $(\mathrm{H} 7)$ than for the conventional vaccine group (H1) or placebo group $(t[27 \mathrm{df}]=5.47 ; P<0.001)$. The NA vaccine was a more immunogenic preparation as measured by antibody response to both the $M$ protein and $\mathrm{HA}$ antigens.

Antibody response after circulation of wild-type "Brazil-like" virus. The presence of Brazil-like influenza virus (H1N1) circulating in the community was documented by rises in the HI titer against the Brazil $\mathrm{HA}$ for sera 4 and 5 . This rise was significant as evaluated by the $F$ test for all groups except the non-ill (possibly noninfected) placebo group $(\mathrm{F}[4,48]=14.68 ; P<0.001)$. Subjects who received conventional vaccine showed a sharp rise in ELISA M titer over that seen for serum 3; subjects who became ill showed a 1.8-fold increase in GMT, and those who were not ill showed a 2.2-fold rise (Table 3 and Fig. 3). Among subjects given placebo injections, those who became ill showed a 2.2 -fold rise in GMT; those who were not ill (possibly noninfected) showed no change in GMT. Subjects who received NA-specific vaccine showed little change in anti-M titer for serum 4 , even though they showed serological evidence of infection with influenza virus as evaluated by $\mathrm{HI}$.

All groups showed a decline in anti-M titer (GMT) from sera 4 to 5 , reflecting a period of about 2 weeks. The average $M$ titers were significantly higher for serum 4 for all groups than for serum 3 or $5(\mathrm{~F}[2,48]=6.65 ; P<0.003)$; the titer for serum 5 was significantly higher than that for serum 3.

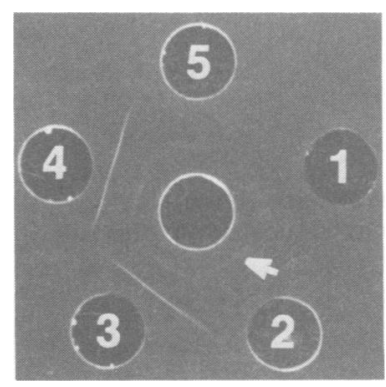

FIG. 2. Immunodiffusion analysis of $\mathbf{M}$ protein (purified from X-53a) and virus preparations (disrupted with $1 \%$ Sarkosyl) tested against serum bleeding 4 from subject 154 (see Table 2). Wells 1 and 2 contained isolated $M$ protein, well 3 contained X-53a (H1N1) virus, well 4 contained $\mathrm{H} 6 \mathrm{~N} 1$ virus, and well 5 contained A/Victoria (H3N2) virus. The precipitin line patterns are compatible with the inner line, representing $M$ protein, and the outer line, shared by wells 3 and 4 , representing NA (N1) protein. 
TABLE 2. Titer of antibodies to HA (as measured by $\mathrm{HI}$ ) and antibodies to $\mathrm{M}$ protein (as determined by ELISA) in subjects receiving Formalin-inactivated vaccines (NA-specific vaccine or conventional H1N1 vaccine) or placebo

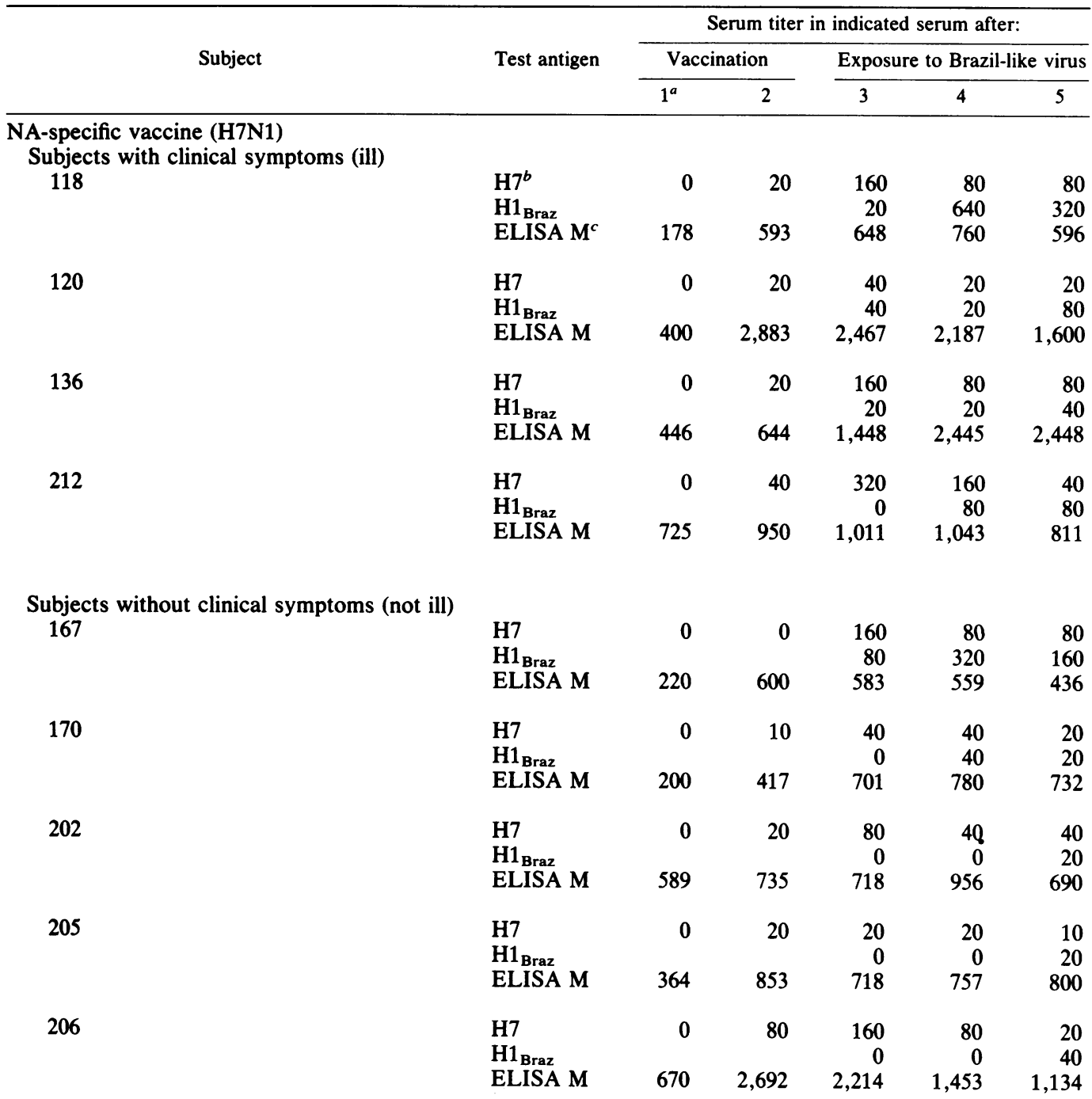

\section{Conventional vaccine (H1N1)}

Subjects with clinical symptoms (ill)

116

$\begin{array}{lrrrrr}\text { H1 } 1_{\text {USSR }} & 0 & 0 & 0 & 40 & 160 \\ \text { H1 } & & & 0 & 160 & 160 \\ \text { ELISA M } & 981 & 1,065 & 1,120 & 1,545 & 1,356\end{array}$

166

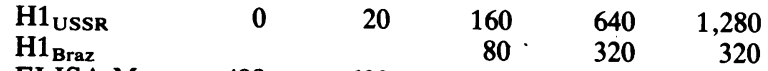

$\begin{array}{lllrrr}\text { ELISA M } & 498 & 600 & 513 & 1,074 & 700\end{array}$

$\begin{array}{lrrrrr}\text { H1 USSR } & 0 & 0 & 0 & 40 & 20 \\ \text { H1 } & & & 0 & 40 & 20 \\ \text { ELISA M } & 1,057 & 1,530 & 1,277 & 1,600 & 1,188\end{array}$


TABLE 2-Continued

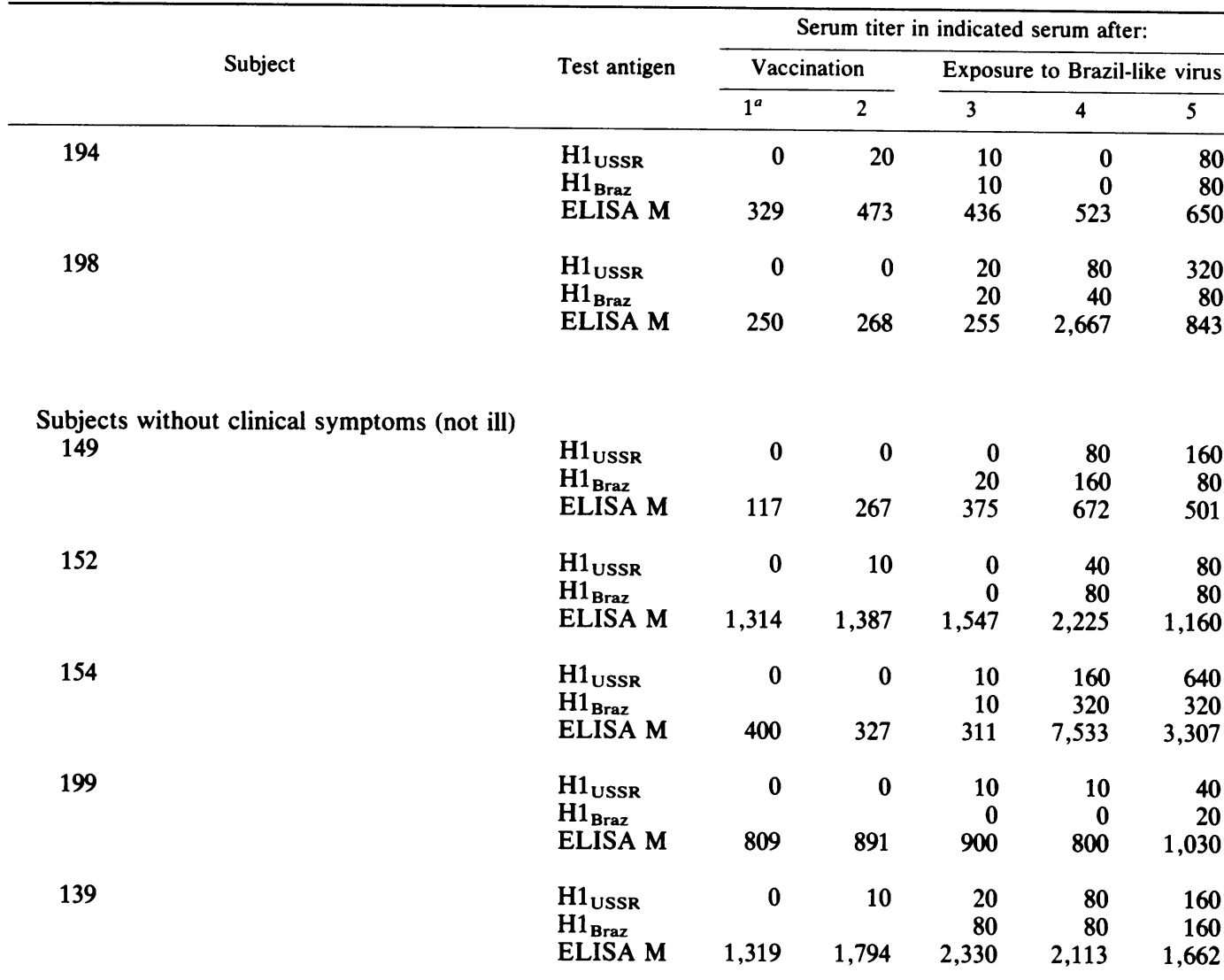

\section{Placebo}

Subjects with clinical symptoms (ill)

117

132

133

136

144

\begin{tabular}{|c|c|c|c|c|}
\hline $\begin{array}{l}\text { H1 } 1_{\text {USSR }} \\
\text { H1 } \\
\text { ELISA M M }\end{array}$ & 1,239 & 471 & $\begin{array}{r}0 \\
0 \\
648\end{array}$ & $\begin{array}{r}0 \\
40 \\
1,128\end{array}$ \\
\hline $\begin{array}{l}\text { H1 } 1_{\text {USSR }} \\
\text { H1 } \\
\text { ELISA M M }\end{array}$ & 1,081 & 1,149 & $\begin{array}{r}20 \\
40 \\
1,192\end{array}$ & $\begin{array}{r}20 \\
40 \\
1,387\end{array}$ \\
\hline $\begin{array}{l}\text { H1 } 1_{\text {USSR }} \\
\text { H1 } 1_{\text {Braz }} \\
\text { ELISA M }\end{array}$ & 567 & 371 & $\begin{array}{r}0 \\
0 \\
518\end{array}$ & $\begin{array}{r}\mathbf{0} \\
\mathbf{0} \\
1,118\end{array}$ \\
\hline $\begin{array}{l}\text { H1 } 1_{\text {USSR }} \\
\text { H1 } 1_{\text {Braz }} \\
\text { ELISA M }\end{array}$ & 150 & 351 & $\begin{array}{r}0 \\
0 \\
220\end{array}$ & $\begin{array}{r}20 \\
80 \\
1,653\end{array}$ \\
\hline $\begin{array}{l}\text { H1 } \\
\text { HSSR } \\
\text { ELISA M } \\
\text { ELISA }\end{array}$ & 757 & 1,029 & $\begin{array}{r}0 \\
0 \\
1,120\end{array}$ & $\begin{array}{r}10 \\
20 \\
1,928\end{array}$ \\
\hline
\end{tabular}

Subjects without clinical symptoms (not ill) 115

$\begin{array}{lrrrrr}\text { H1 USSR } & 0 & 0 & 0 & 0 & 0 \\ \text { H1 } & & & 80 & 160 & 40 \\ \text { ELISA M } & 337 & 507 & 544 & 489 & 384\end{array}$


TABLE 2-Continued

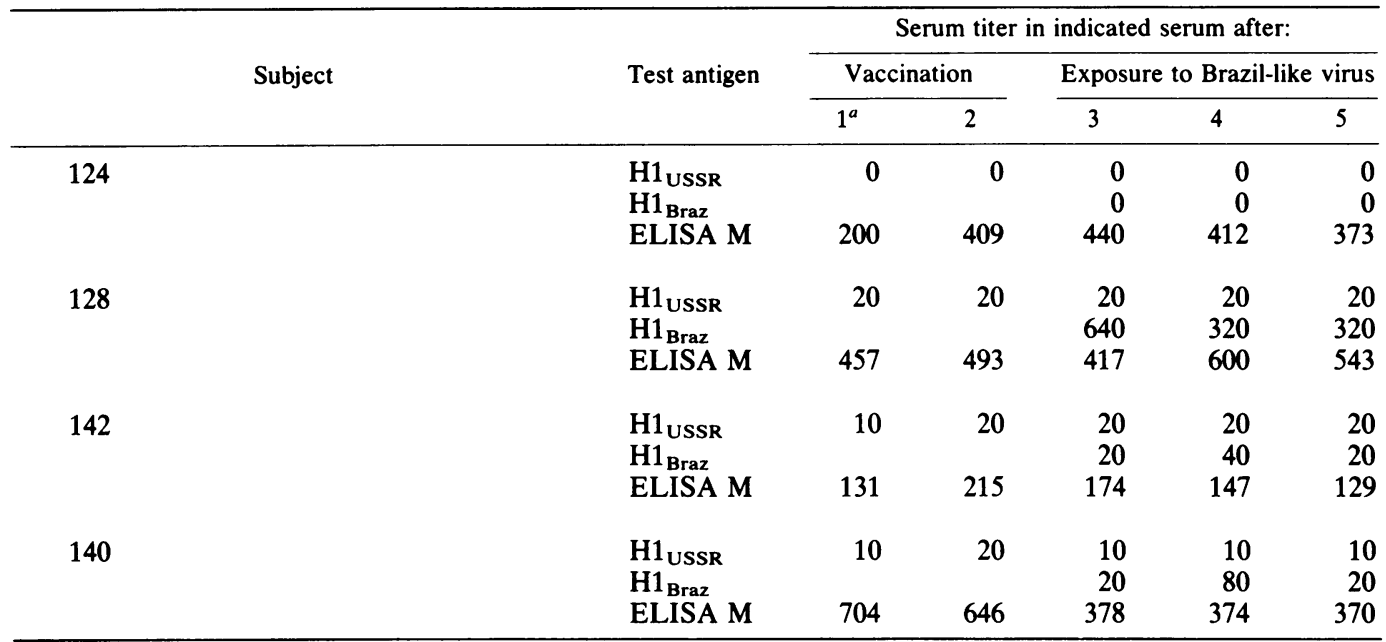

${ }^{a}$ Initial bleeding (see Table 1).

${ }^{b}$ See text for specific viruses used.

${ }^{c} \mathrm{M}$ antigen (PR8) from X-532 vaccine.

The highest titer responses to $\mathrm{M}$ protein were observed in subjects 198 and 154, both of whom were vaccinated with conventional vaccine. Subject 198 showed more than a 10 -fold rise in antibody titer to M protein; subject 154 showed a 24-fold rise and had no clinical symptoms of illness.

Dissociation of antibody response to $M$ protein from response to $H A$ or NA. Dissociation of antibody response to $M$ protein from response to

TABLE 3. Antibody response to HA (HI) and M protein (ELISA) GMTs

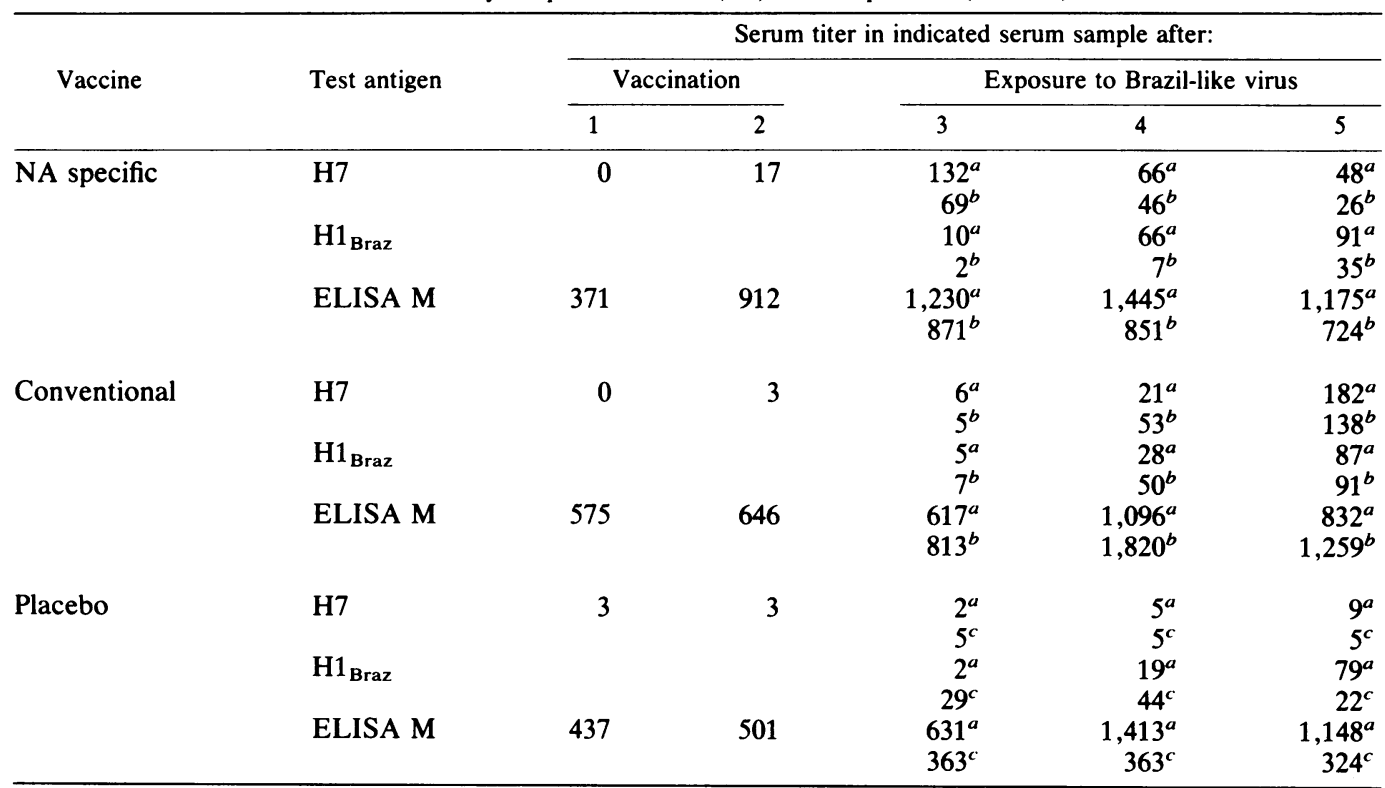

${ }^{a}$ Subjects who developed clinical symptoms of influenza upon exposure to circulating Brazil-like influenza virus.

${ }^{b}$ Subjects with no clinical symptoms of influenza who had serological evidence of infection.

${ }^{c}$ Subjects with no clinical symptoms of influenza who may not have been infected. 


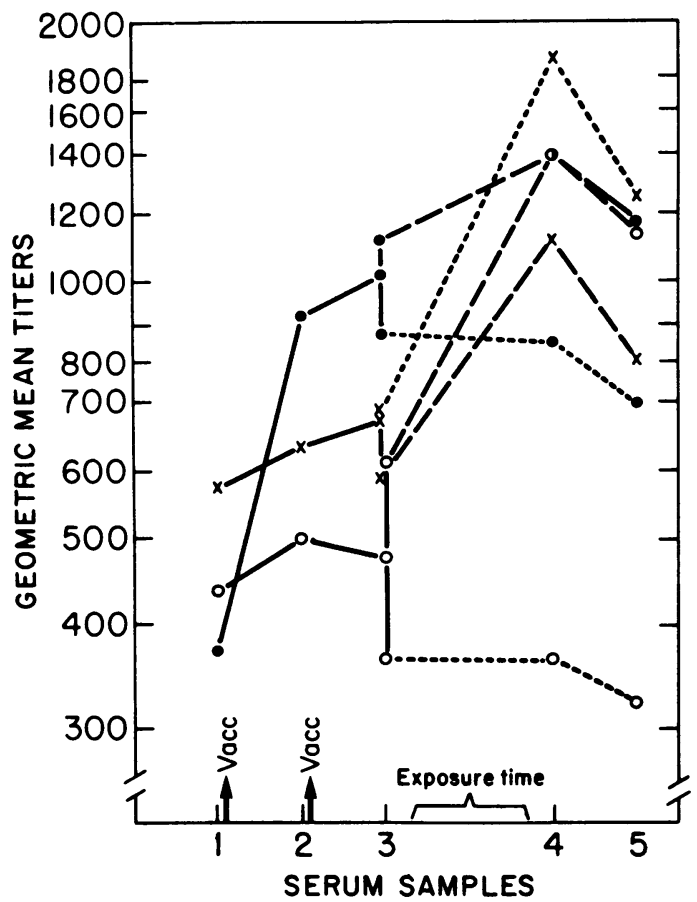

FIG. 3. GMTs of $M$ antibody level at various periods (see also Table 3). NA-specific vaccine, conventional vaccine, and placebo groups are each considered as a single group through serum samples 1,2 , and 3. These groups diverged into ill and non-ill categories by response at periods 4 and 5. GMTs are shown for ill and non-ill subjects for periods 3, 4, and 5. GMTs of subjects in the different vaccine categories are designated as follows: $\bigcirc$, NA-specific vaccine; $\times$, conventional vaccine; $O$, placebo. Divergence of each of the vaccine groups at period 3 is designated as ill (- --$)$ or non-ill (----).

the surface antigens (HA and NA) was seen in several cases after either infection or vaccination. Subjects 118 (NA-specific vaccine) and 132 (placebo) attained HI titers of 640 to H1 (Brazil) in their sera for bleeding 4 or 5 , whereas the anti$M$ titer rose only slightly. Subject 198 (conventional vaccine) showed a 10 -fold rise in titer to $M$ protein but attained an HI titer of only 80 . Subject 120 (NA-specific vaccine) showed a sevenfold rise in $\mathbf{M}$ antibodies upon immunization, whereas the rise in antibodies to N1 NA in an ELISA test system was only 1.6-fold (7).

Rises in anti-M titer preceded or were coincident with rises in titer to HA. In no instance was a rise in antibody titer to HA followed by a subsequent rise in antibody titer to $M$ protein, as determined in sera 4 and 5 after the circulation of H1N1 (Brazil) in this population. Of 29 subjects (subject 27 had no detectable HI antibody and was excluded), 10 showed a peak in $M$ titer at bleeding 4 , followed by a peak in HI titer at bleeding $5 ; 14$ subjects had a coincident rise in titer of antibodies to $\mathrm{M}$ and $\mathrm{HA}$ at time 4 ; and 5 subjects showed a simultaneous increase in antibody titer to $\mathrm{M}$ and $\mathrm{HA}$ at bleeding 5 .

\section{DISCUSSION}

Antibodies to the type-specific $M$ protein of influenza virus were measured by the single radial immunodiffusion test in previous studies $(5,11)$. From these studies, it was concluded that only persons severely infected by influenza viruses demonstrated measurable antibody levels to $M$ protein. With the ELISA system, our study revealed increases in $\mathbf{M}$ antibody titers in subjects who were immunized by either natural infection or inactivated vaccine. Although definitive analysis has not yet been made of the complete vaccine study with respect to the relationship of symptoms to specific serological responses, several subjects who were not clinically ill but who were confirmed as having been infected by serological techniques (HI) also showed a rise in $\mathbf{M}$ antibody titers.

The conventional vaccine was poorly immunogenic with respect to both $M$ protein and HA antigens, as measured by antibody response. The reason for this lack of immunogenicity remains unclear. Both NA-specific and conventional vaccines were prepared by similar techniques of Formalin inactivation and contained similar antigenic mass according to HA titers. Upon natural infection, antibody responses to $M$ protein did not differ significantly between the conventional vaccine and placebo (ill) groups; the titers in these groups approached the apparently maximal response seen in the NA-specific vaccines.

The dichotomous immune responses to HA and $M$ protein both quantitatively and temporally (i.e., antibodies to $M$ protein appeared earlier in the immune response) suggest that, in most subjects, $\mathbf{M}$ antibody response is a secondary response to broadly reactive antigens of this protein common to all influenza virus strains and subtypes. The earlier antibody response to $M$ protein may not provide any significant advantage over the HI test in epidemiological studies; however, it should facilitate detection of response to variant influenza $A$ viruses which differ from that represented in the test antigen (HA).

It is uncertain how antibodies to $M$ protein participate either in preventing influenza virus infection or in the development of disease. Cretescu et al. (5) have studied anti-M responses in humans by single radial immunodiffusion and have suggested that anti-M may play a small role in cross-protection between different influenza subtypes or may be associated immunopathologically with the disease. Webster and Hinshaw (18) found that mice which had been previously 
immunized with $\mathbf{M}$ protein showed more rapid clearance of virus from their lungs than did unimmunized mice; however, the immunized mice developed pneumonia which was as severe as that of the unimmunized group.

The possible role of $\mathbf{M}$ protein and its antibodies in influenza or syndromes which have been associated with influenza virus immunization or infection such as Guillain-Barre and Reye's syndromes can be studied with the techniques outlined in this paper.

\section{ACKNOWLEDGMENTS}

This research was supported in part by a contract from Lederle Laboratories and by the U.S. Army Research and Development Command under research contract DADA17-69C-9137. Research support was also provided by Public Health Service grant AI-16073 from the National Institute of Allergy and Infectious Diseases.

The technical collaboration of Su Lin, Tatiana Kamenar, and Natasha Khelemskaya is gratefully acknowledged. We also acknowledge the expert assistance of Anita Spingarn in preparation of the manuscript and of Ellen Felten in preparation of the graph.

\section{LITERATURE CITED}

1. Aymard-Henry, M., M. T. Coleman, W. R. Dowdle, W. G. Laver, G. C. Schild, and R. G. Webster. 1973. Influenza neuraminidase-inhibition test procedures. Bull. W.H.O. 48:199-202.

2. Bucher, D. J. 1975. Chromatographic isolation of the major polypeptides of influenza virus, p. 133-143. In B. W. J. Mahy and R. D. Barry (ed.), The negative strand viruses, vol 1. Academic Press, Inc., London.

3. Bucher, D. J., I. G. Kharitonenkov, J. A. Zakomirdin, V. B. Gregoriev, S. M. Klimenko, and J. F. Davis. 1980. Incorporation of influenza virus M-protein into liposomes. J. Virol. 36:586-590.

4. Bucher, D. J., S. S.-L. Li, J. M. Kehoe, and E. D. Kilbourne. 1976. Chromatographic isolation of the hemagglutinin polypeptides from influenza virus vaccine and determination of their amino terminal sequences. Proc. Natl. Acad. Sci. U.S.A. 73:238-242.

5. Cretescu, L., A. S. Beare, and G. C. Schild. 1978. Forma- tion of antibody to matrix protein in experimental human influenza A virus infections. Infect. Immun. 22:322-327.

6. Hierholzer, J. C., M. T. Suggs, and E. C. Hall. 1969. Standardized viral hemagglutination and hemagglutination-inhibition tests. II. Description and statistical evaluation. Appl. Microbiol. 18:824-833.

7. Khan, M. W., M. Gallagher, D. Bucher, C. Cerini, and E. D. Kilbourne. 1982. Detection of influenza virus neuraminidase-specific antibodies by an enzyme-linked immunosorbent assay. J. Clin. Microbiol. 16:115-122.

8. Kilbourne, E. D. 1978. Genetic dimorphism in influenza viruses: characterization of stably associated hemagglutinin mutants differing in antigenicity and biological properties. Proc. Natl. Acad. Sci. U.S.A. 75:6258-6262.

9. Lowry, O. H., N. J. Rosebrough, A. L. Farr, and R. J. Randall. 1951. Protein measurement with the Folin phenol reagent. J. Biol. Chem. 193:265-275.

10. Masihi, K. N., and W. Lange. 1980. Enzyme-linked immunosorbent assay for the detection of influenza typespecific antibodies. J. Immunol. Methods 36:173-179.

11. Mostow, S. R., G. C. Schild, W. R. Dowdle, and R. J. Wood. 1975. Application of the single radial diffusion test for assay of antibody to influenza type A virus. J. Clin. Microbiol. 2:531-540.

12. Murphy, B. R., M. A. Phelan, D. L. Nelson, R. Yarchoan, E. L. Tierney, D. W. Alling, and R. M. Chanock. 1981 . Hemagglutinin-specific enzyme-linked immunosorbent assay for antibodies to influenza A and B viruses. J. Clin. Microbiol. 13:554-560.

13. O'Farrell, P. H. 1975. High resolution two-dimensional electrophoresis of proteins. J. Biol. Chem. 250:4007-4021.

14. Oxford, J. S., and G. C. Schild. 1976. Immunological and physiochemical studies of influenza matrix (M) polypeptides. Virology 74:394-402.

15. Palese, P., M. B. Ritchey, J. L. Schulman, and E. D. Kilbourne. 1976. Genetic composition of a high yielding influenza A virus recombinant: a vaccine against swine influenza. Science 194:334-335.

16. Palmer, D. F., W. R. Dowdle, M. T. Coleman, and G. C. Schild (ed.). 1975. Advanced laboratory techniques for influenza diagnosis. Department of Health, Education. and Welfare, Public Health Service, Centers for Disease Control, Atlanta, $\mathrm{Ga}$.

17. Voller, A., D. E. Bidwell, and A. Bartlett. 1976. Enzyme immunoassays in diagnostic medicine. Bull. W.H.O. 53:55-65.

18. Webster, R. G., and V. S. Hinshaw. 1977. Matrix protein from influenza $\mathrm{A}$ virus and its role in cross-protection in mice. Infect. Immun. 17:561-566. 